\title{
Comparative Analysis on Training Objectives of Logistics Management Professionals at Different Levels
}

\author{
Shijun Yuan \\ Hunan Modern Logistics College \\ Changsha, China
}

\begin{abstract}
This paper compares and analyzes the objectives of the "secondary vocational-higher vocationalundergraduate" logistics management professional training from the three levels of policy, academia and college practice, and proposes that colleges and universities of different levels should make clear personnel training objectives according to their own conditions to meet the needs of logistics personnel of different levels of society.
\end{abstract}

Keywords-logistics management; profession; training objectives

\section{INTRODUCTION}

There is no clear policy requirement for the provision of logistics management in higher vocational colleges. Higher vocational colleges generally refer to the "Standards for the Establishment of Higher Vocational Schools of the Ministry of Education (Provisional)" and "Teaching Standards for the Logistics Management Major of Higher Vocational Schools" for implementation. In the "Standards for the Establishment of Higher Vocational Schools of the Ministry of Education (Provisional)", in addition to the clear requirements for teachers of professional setting — "every professional equipped with high professional technical position at least 2 or more full-time teachers, 2 full-time professional teachers above the intermediate professional title of 'doublequalified'", and there are only general descriptions of the practical training places, teaching equipment and books and reference materials. "Teaching Standards for the Logistics Management Major of Higher Vocational Schools" includes ten parts of "professional name, professional code, enrollment target, academic system and academic qualifications, employment orientation, training objectives and specifications, professional certificate, curriculum system and core curriculum, basic conditions for professional education and teaching suggestions, continuing professional study and further study", standardizing the teaching implementation of logistics management in higher vocational colleges.

The rapid development of the logistics industry has brought about a sharp increase in the demand for logistics talents. The compound logistics industry has determined that the demand for logistics talents is also multi-layered. The cultivation of logistics talents in China's existing education system covers the secondary vocational, higher vocational and undergraduate levels. This paper compares and analyzes the talent training objectives of different levels of institutions

\section{POLICY LEVEL}

\section{A. Secondary Vocational Schools}

According to the "Teaching Standards for Logistics Service and Management in Secondary Vocational Schools (Consultation Draft)" organized by the National Logistics Vocational Education Teaching Steering Committee and completed by experts, the goal of personnel training is "for logistics enterprises and enterprise logistics departments, to adapt to the development needs of China's logistics industry, to cultivate high-quality laborers and skilled personnel to serve the front-line logistics work with... solid logistics services and management specialized knowledge."

\section{B. Higher Vocational Schools}

The "Decision of the State Council on Accelerating the Development of Modern Vocational Education" proposes that "specialized higher vocational colleges should closely cooperate with industry, university and research institutes to train technical personnel for service area development." Therefore, the goal of training professionals in higher vocational logistics management should be "to cultivate logistics technical and skilled personnel for regional development".

\section{Undergraduate Schools}

In 2008, the "Guiding Opinions on the Undergraduate Professional Training Program for Logistics Management (Trial)" formulated by the Logistics Steering Committee of the Ministry of Education of the Ministry of Education clearly stated that the professional training of logistics management undergraduates should...make them familiar with the relevant regulations of logistics management, master systematic supply chain and theoretical knowledge of logistics management and cultivate compound logistics management talents who can engage in logistics system optimization, logistics business operations and logistics management. 


\section{THE ACADEMIC LEVEL}

\section{A. Secondary Vocational Schools}

Lin Yun (2006) believes that the secondary vocational schools aim to train the front-line operators who understand the logistics process and have certain professional ability. Guo Dongqing (2010) believes that the secondary vocational schools should face the grassroots, production, and service and management coverage of transportation, warehousing and distribution, marketing, information to cultivate the firstline of practical and skilled talents. Zhou Bin (2013) believes that the main talents trained in secondary vocational schools are logistics junior talents and general operators, that is, onsite operations of specific logistics activities.

\section{B. Higher Vocational Schools}

Huang Huichun et al. (2008) believed that the professional logistics management profession should adapt to the needs of the society for logistics talents, and cultivate application-oriented professionals who can serve in the fields of warehousing, distribution, and procurement. Gou Jianhua (2008) believed that the first-line application talents should be cultivated according to the specific jobs of the logistics departments and logistics enterprises of production enterprises or commercial circulation enterprises. Hu Fang (2009) believed that the major of higher vocational logistics management should be based on the requirements of the actual positions of enterprises on their ability and quality, "aiming at training all kinds of applied talents of logistics technology application and logistics management and service in the first-line of enterprise logistics". Chen Shiying (2010) proposed that the logistics talents cultivated in higher vocational colleges are "wide-calibre, thick-based, comprehensive and applicable" compound talents. The theoretical knowledge of talent cultivation is positioned as the middle and primary level and the practical skills should be equipped with the skills required by the national logistician (including assistant logistician) standard. Wu Xiaoyan (2010) started from the regional industry and logistics development in Shanghai, and proposed the personnel training objectives and curriculum system of "port logistics", "manufacturing logistics" and "urban distribution logistics".

\section{Undergraduate Schools}

Cao Caijie (2008) believed that the undergraduate course of logistics management is training applied talents. Its knowledge goal is to master the basic theory of logistics management and the knowledge of related disciplines. Its ability goal is to have the logistics operation management ability of a certain professional field, and $\mathrm{Cao}$ also proposed a curriculum system that includes the basic modules, professional modules, professional development modules, and training modules to achieve the goal of talent training. Tang Limin et al. (2009) comprehensively considered and proposed, from the three dimensions of activity scope (dimensional), activity content (dimensional) and activity level (dimensional), the goal of logistics management talent training of Dalian Maritime University is to cultivate compound professionals who can engage in logistics system planning and design and logistics activities management Industrial and commercial enterprises, port and shipping enterprises, logistics enterprises and government-related management departments are their main job positions. Han Xiaohua (2010) proposed measures for the cultivation of "application-oriented" talents in logistics management. Chen Haixia et al. (2011) put forward the goal of training undergraduate logistics management talents with "fine professional, foreign language, and heavy practice". And put forward solutions in a targeted manner.

\section{THE PRACTICE LEVEL OF COLLEGES AND UNIVERSITIES}

\section{A. Secondary Vocational Schools}

Logistics finance management major of Xiangbei Vocational Secondary School in Hunan Province aims to: cultivate highly skilled and application-oriented professionals with basic theoretical knowledge in the field of logistics management, familiar with the business process of logistics management, master relevant basic operational skills, and adapt to the needs of the first line of logistics management. And can independently engage in logistics and corresponding transportation, warehousing, storage and other work.

Logistics management major of Liuyang City Vocational Secondary School aims to face the front-line of logistics industry to train high quality skilled personnel with modern logistics concepts, mastering the basic theoretical knowledge and professional skills necessary for logistics management, with high comprehensive quality and good professionalism, can engage in logistics industry customer service supervisor, sales clerk, freight forwarder operator, vouching clerk, customs declarer/inspection staff, transportation supervisor, warehouse supervisor, etc.

Logistics management major of Secondary Vocational Schools in Jiangsu Province: It mainly trains high-quality workers and skilled personnel who serve the front-line of logistics enterprises and enterprise logistics departments, adapt to the development needs of China's logistics industry, have a healthy body and mind, basic scientific and cultural literacy, continuous learning ability and innovative spirit, good professional ethics, solid logistics service and management expertise, strong safety production and environmental awareness, strong employability and certain entrepreneurial ability. Among them: Graduates in the direction of warehousing and distribution should be able to skillfully carry out operations such as warehousing, storage, delivery, return processing and distribution, and be skilled in applying warehousing and distribution related equipment and information systems; graduates of transportation business should be able to skillfully complete transportation business acceptance, expense accounting, document filling, goods collection, vehicle loading, loading and shipping, in-transit tracking and other operations, and be able to skillfully use transportation related equipment and information system; international freight forwarding graduates should be able to complete goods collection, space booking, storage, transit 
shipment, bill making, bill checking, scheduling, container transportation and freight settlement, familiar with customs clearance, customs inspection, insurance and other work processes, familiar with the application of relevant information system; graduates of express delivery business should be able to skillfully complete operations such as express collection, sorting, sealing, transshipment, delivery, information entry, inquiry, market development, and troublefree shipment processing, and skillfully apply express-related equipment and information systems.

\section{B. Higher Vocational Schools}

Logistics management major of Hunan Modern Logistics College is a model specialty in Hunan Province. The goal of talent training in the enterprise logistics direction is: for the logistics department of industrial and commercial enterprises or the front-line management position of logistics industry... to cultivate high quality technical talents with modern logistics concept, mastering logistics management professional (enterprise logistics direction) necessary professional theoretical knowledge and logistics management expertise, ... can engage in industrial manufacturing logistics department procurement and supply, production logistics management, production of finished products and raw materials accessories storage operations and management, logistics distribution, sales and recycling logistics, logistics information management and other work.

Logistics management major of Hunan Industry Polytechnic: To cultivate advanced technology application talents who are familiar with logistics operation process, master the basic knowledge and operational skills of logistics management, with logistics organization management ability, market development ability, logistics business operation ability, can engage in logistics information processing, distribution, warehousing, procurement, freight forwarding and logistics management and other work.

\section{Undergraduate Schools}

Logistics management major of Hunan Business College: To cultivate application-oriented professionals who are familiar with logistics management regulations, master rich logistics operation knowledge... capable of logistics business operations, logistics management and supply chain logistics system optimization and other work.

School of transportation and logistics, Central South University of Forestry and Technology, logistics management major: To cultivate advanced technology and management talents with the basic theory and basic knowledge of modern logistics discipline, can engage in international logistics operation and management, regional logistics planning and management, enterprise logistics planning and management, and third-party logistics operations and management, supply chain integration operation and management, logistics marketing and logistics information construction and other work.

\section{CONCLUSION}

In order to meet the needs of all levels of logistics talents in an all-round way, secondary vocational schools, higher vocational schools and undergraduate schools should have a clear and clear orientation in the training objectives of logistics management personnel in light of the actual situation of the schools. Generally speaking, the secondary vocational schools should be positioned at cultivating highquality laborers and skilled talents in the front-line of logistics activities; higher vocational schools should be positioned to cultivate skilled personnel who operate modern logistics facilities and use modern logistics office software and logistics skills and basic management skills; undergraduate schools should be positioned to cultivate midlevel logistics operations and management compound talents who are familiar with the logistics enterprise operation process and can possess multi-faceted knowledge, coordination management ability and certain strategic decision-making ability. At the same time, in a briefer way, the author believes that the main position of the secondary vocational school is the first-line high-quality laborers of logistics activities; the higher vocational position is mainly the trainers and managers of the first-line high-quality laborers of logistics activities; the undergraduate is mainly positioned as the designer and manager of the middle and high level logistics activities.

\section{REFERENCES}

[1] Chen Haixia et al. Analysis of the training methods of logistics management professionals based on the training objectives of "fine professional, foreign language, and heavy practice" [J]. Logistics Science and Technology. No.9, 2011, 134-135. (in Chinese)

[2] Zhou Bin. Discussion on the multi-level training of logistics talents in the middle school-high vocational-application undergraduate connection education in logistics management [J]. Logistics Engineering and Management. No.12, 2013, 214-215. (in Chinese) 